\title{
Graduates Registered and Number of Dropouts in the College Technological Courses of the Federal Institute of Amapa, Brazil, Between 2012 and 2017
}

\author{
LAURINDO, Caio Felipe ${ }^{[1]}$, FECURY, Amanda Alves ${ }^{[2]}$, OLIVEIRA, Euzebio de ${ }^{[3]}$, DENDASCK, \\ Carla Viana ${ }^{[4]}$, MATTOS, Claudio Alberto Gellis de ${ }^{[5]}$
}

LAURINDO, Caio Felipe; et.al. Graduates Registered and Number of Dropouts in the College Technological Courses of the Federal Institute of Amapa, Brazil, Between 2012 and 2017. Multidisciplinary Scientific Journal. Year 03, Ed. 06, Vol. 02, pp. 05-14, June 2018. ISSN: 2448-0959

\begin{abstract}
Generate higher level of knowledge to enable the exercise of the unit of management of higher education competences, although it is a matter of institutional prominence, to allow the construction of a language useful for the control of evasion by college, which involves a complex area, broad and interdisciplinary, addressing pedagogical, administrative, historical, political, socioeconomic, psychological, among others. Given the few studies and policies directed on Evasion in Brazilian Higher Education, especially on the technological courses, on this important subject, the present work proposed to identify the profile of the students evaded of the superior courses and technology of Campus Macapá of the Federal Institute of Amapá (IFAP), Brazil, identify patterns that indicate possible causes of evasion. Secondary data obtained from the academic record of the Macapá campus were used, which still received analytical treatment, being quantified the students evaded, either by abandonment or disconnection. It was sought to identify the causes that influence evasion, based on a comparison between data from the general group of students and the group of evaders, regarding: year of evasion and class of students, number of students classified according to the form of admission (quota used), age, sex, candidates / vacancies in the year of entry of the course, period. The subjects of the survey were students who had escaped from the Macapá Campus higher education courses, enrolled in the IFAP courses between 2012 to 2017. The results lead to the conclusion that evasion has important impacts on the courses studied and that the profile of the students evaded of the courses analyzed is atypical in relation to the profile of evadidos raised in other works on the subject, it was also approached some actions that can minimize the causes and the factors of the evasion in the studied Institution.
\end{abstract}


Keywords: Dropout, Federal Institute, Technical College

\section{Introduction}

The institution of higher education (college) has the social function of generating higher level knowledge to enable the functioning of society. This role manifests itself differently depending on the type of society (PEREIRA, 1997). Brazilian higher education is seen with many inequalities, since Brazil is located in South America, a poor continent, both in the social context and in the territorial sphere, with the greatest number of unequal indexes in several aspects, including among them : distribution of income, expenditures on consumer goods, services, access to health and, above all, access to education. Even so, the university since its inception, has assumed a much greater role than its formative responsibility. It brings to you the decision to train citizens committed to social commitment, to the struggle to reduce inequalities, to create opportunities for all, as well as access to the labor market for income generation, environmental, economic and social development. Social; and with the construction and maintenance of cultural identities (STALLIVIERI, 2006).

Higher technological education manifests itself as a sequence of a struggle for the democratization of scientific and technological knowledge, for an improvement in the quality of life and almost immediate attendance of skilled labor, but the conclusion of these courses is still concentrated in the hands of a few. The organization of teaching reflects on the training of students and how they will act in society. It should be clear that official policy, by appropriating and redirecting this theme from a pragmatic and utilitarian perspective of market adjustment, reduces the social function of higher education to the ideals of preparation for work, by redefining professional profiles based on skills and competencies. (VOLPI, 2009).

Avoidance in higher education is an important problem to be investigated in the processes of institutional evaluation, with the objective of establishing suitable means to determine future events and control of evasion by the Institution of Higher Education (IHE), which involves a complex, broad and interdisciplinary area that pedagogical, administrative, historical, political, socioeconomic, psychological, among others. (SCALI, 2009).

According to Lobo (2012), the evasion is seen under aspects of educational management in the IHE, belatedly acknowledged that there are many issues that involve evasion, abandonment of the student without completing their studies, consequently, social losses, resources, damages for all involved with education, institution and all Brazilian society. There are few studies and policies directed on Evasion in Brazilian Higher Education, it should have a general governmental policy focused on academic quality, the responsibility of the use of public and private resources, aiming at the permanence of the student in the IHE.

Thus, the present study identified from the secondary data the profile of the evaders in these courses, seeking by means of comparisons between this public and the finalists the identification of patterns that indicate possible causes of evasion. Thus, alternatives are proposed for the control of evasion, so that the students reach the conclusion of graduation successfully, and consequently the institution achieves its objectives of providing ample and qualified training to its students.

This article aimed to evaluate the evolution in the number of registered students and the number of 
evasions, and the possible causes of these in the technological superior courses of IFAP, campus Macapá, between 2011 the end of the first half of 2017.

\section{Method}

The present study refers to evasion in the higher technology courses of the Federal Institute of Amapá, Campus Macapá, within the quantitative categorization, both in the form of collection of documentary information.

Data collection was done through documentary research and the use of secondary data obtained from the academic registry of the Macapá campus of IFAP.

A descriptive research was used as a methodological outline that, according to Gil (2009), has as main objective the characterization of a certain population, sample, or phenomenon or the establishment of variable relations.

Quantitative research considers that everything can be quantifiable, which means translating into numbers, opinions, information to classify and analyze them (SILVA e MENEZES, 2005).

For the purpose of calculating the dropout by course, the students of the higher technology courses of the Macapá Campus, of the IFAP, who were asked to leave or abandon their courses, were quantified. The first group corresponds to students who have applied for their enrollment. The second group refers to students who no longer apply for their enrollment. In the case of the last group, it is possible for the students to return, with the authorization of the course coordinator.

In this context, we sought to identify the causes that influence evasion, based on a comparison between data from the general group of students and the group of evaders regarding: year of avoidance, course, competition for admission to the course, admission form quota), age, sex, candidates / vacancies in the year of enrollment in the course, period studied.

The subjects of the research were students of the upper courses of Macapá Campus, enrolled in the upper courses of IFAP between the years of 2012 and the end of the first semester of 2017.

\section{Results}

Graph 1 shows the number of students enrolled per course per year. The evolution of enrolled students is marked by an increase in all courses over the years. 


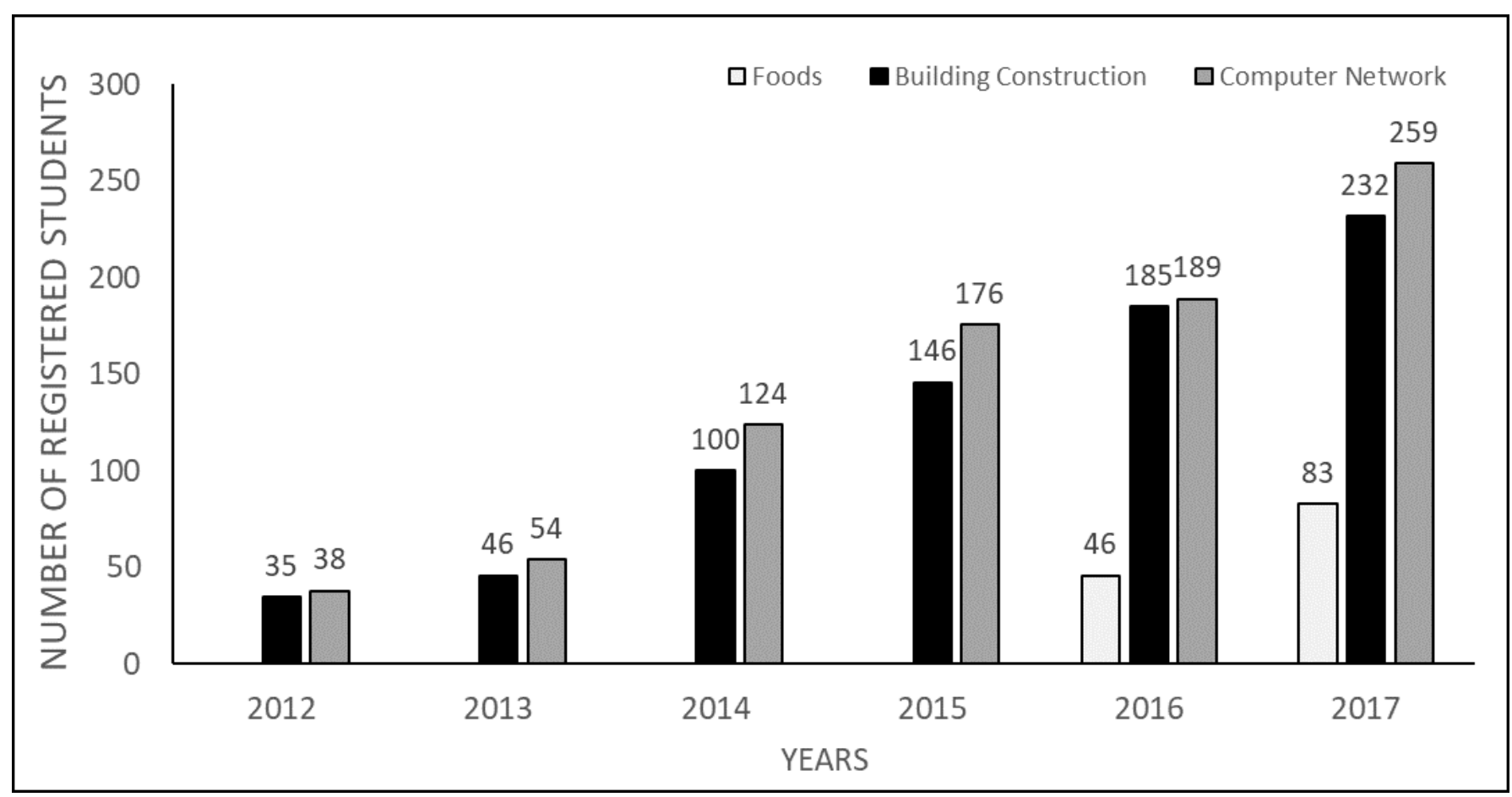

Graph 1 - Shows the number of students enrolled per course per year.

Graph 2 shows the number of concluding students per course, per year. There are no graduates of the Foods course because it is a more recent course. By the second half of 2017, the Computer Network course had sixteen graduates, and the Technology in Building Construction course had only two graduates. 


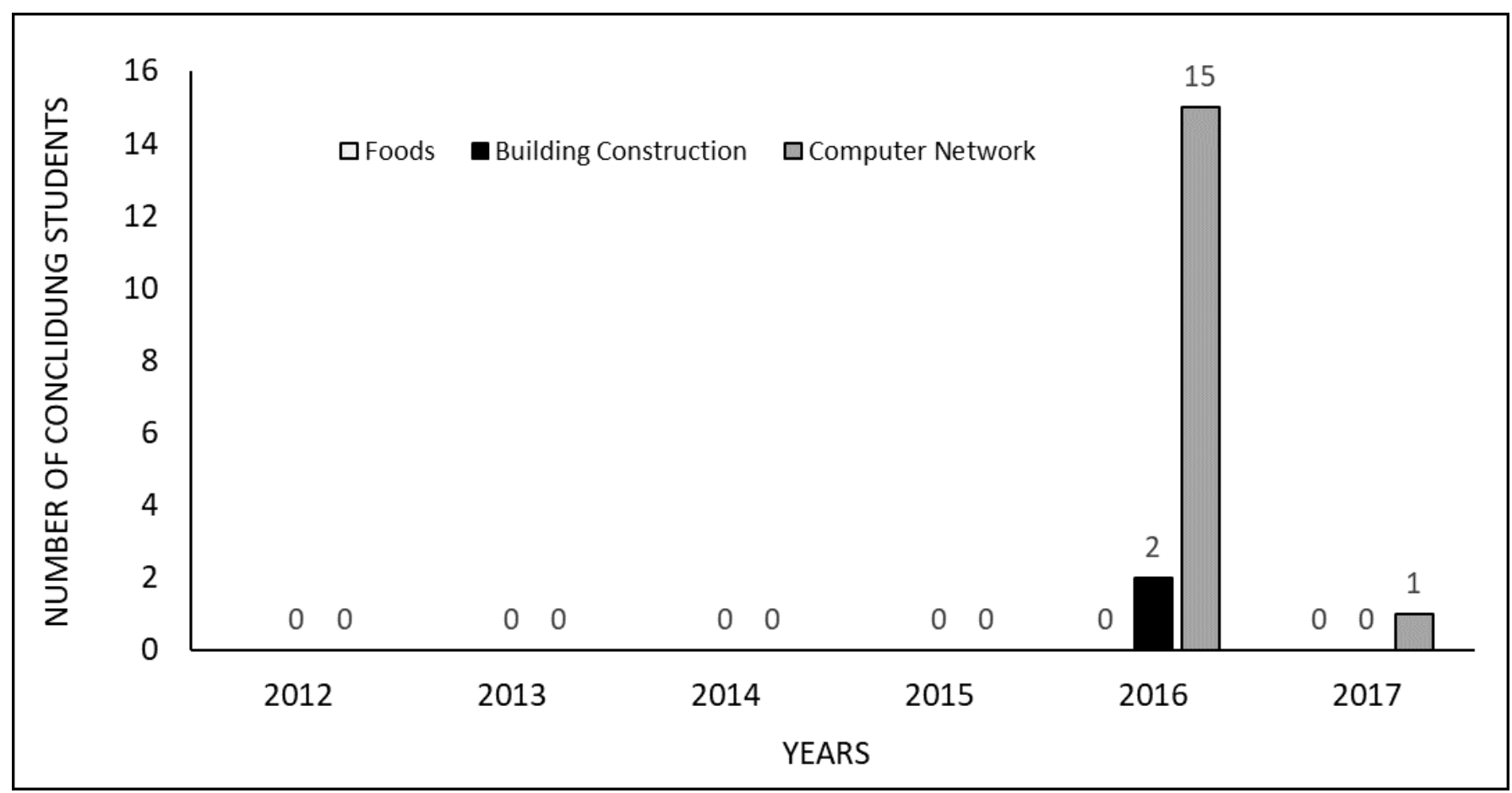

Graph 2 - Shows the number of concluding students per course, per year.

Graph 3 shows the number of graduates who dropouted your studies per year/per course. The Building Construction course presented a reduction in the number of evaders over time, except for the year 2015 where it had an increase for 13 dropout. The Computer Network course has fluctuated almost every year as far as the evolution of the evaders. Already the Foods course presented a significant increase of dropout. 


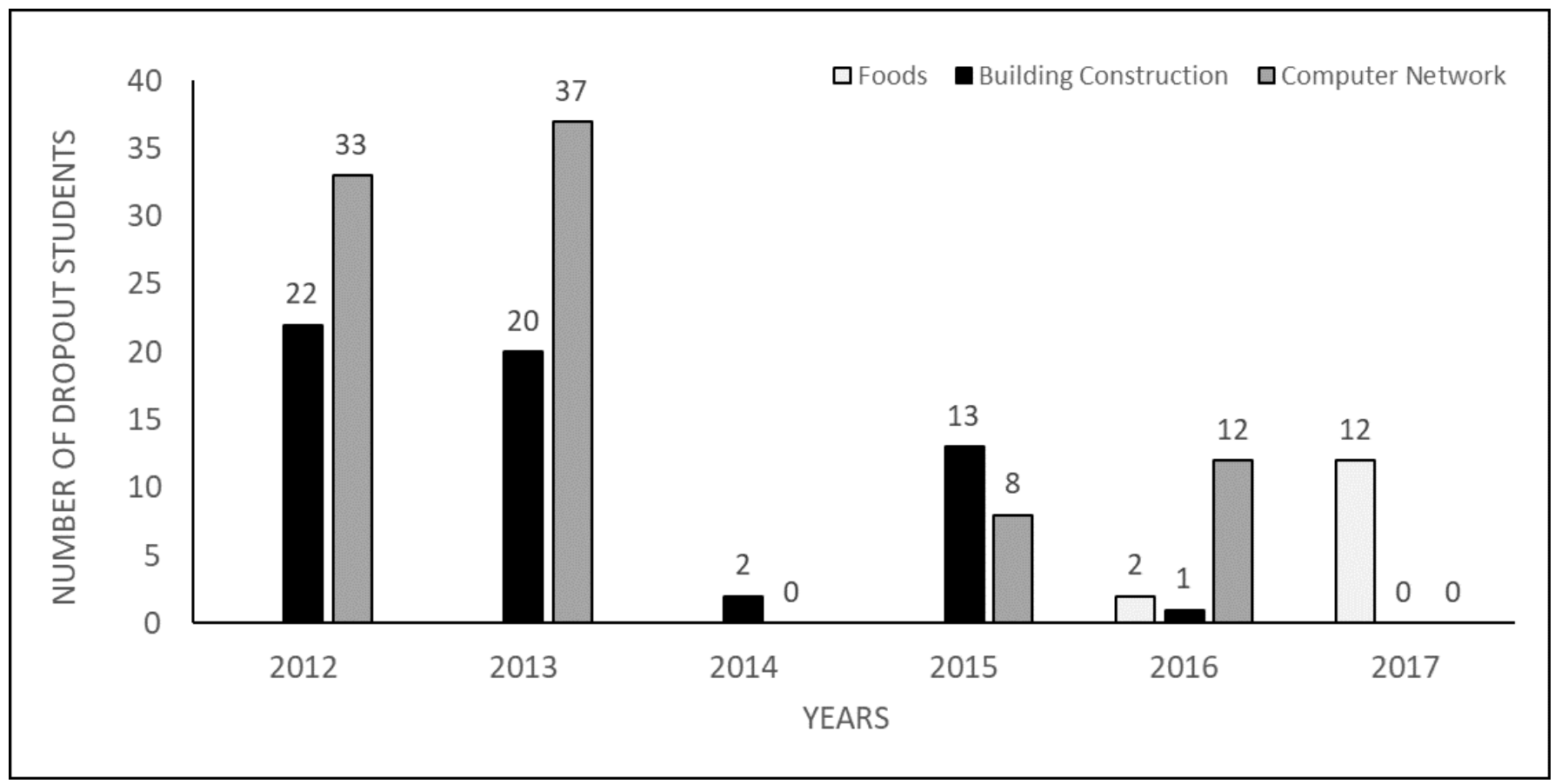

Graph 3 - Shows the number of graduates who dropouted your studies per year/per course.

Table 1 shows comparisons between the profile of the evaders and the general profile of the enrolled students. When considering the characteristics of the student dropout in comparison with the general profile of the enrolled students, it is observed that the percentage of student participants among the dropouts is smaller than the one found in the general profile. The higher the data distribution is the greater the difference between the series and the six-year-old and among the dropouts compared to the total. Finally, a competition for entry into the course is higher among the dropouts than the general average.

\begin{tabular}{l|c|c|c|c|c}
\cline { 2 - 6 } & $\begin{array}{c}\text { with } \\
\text { racial } \\
\text { quota }\end{array}$ & $\begin{array}{c}\text { 20 years } \\
\text { or less }\end{array}$ & $\begin{array}{c}\text { 21 and 25 } \\
\text { between } \\
\text { years }\end{array}$ & $\begin{array}{c}\text { 26 years } \\
\text { and over }\end{array}$ & $\begin{array}{c}\text { Average } \\
\text { competition } \\
\text { (Signed for } \\
\text { vacancy) }\end{array}$ \\
\hline Dropout & 28 & 39 & 34 & 89 & 64,75 \\
Dropout (\%) & $17, \mathbf{2 8} \%$ & $\mathbf{2 4 , 0 7 \%}$ & $\mathbf{2 0 , 9 9 \%}$ & $\mathbf{5 4 , 9 4 \%}$ & $\mathbf{X}$ \\
Total & 146 & 180 & 139 & 271 & 59 \\
Total (\%) & $\mathbf{2 4 , 7 5 \%}$ & $\mathbf{3 0 , 5 1 \%}$ & $\mathbf{2 3 , 5 6 \%}$ & $\mathbf{4 5 , 9 3 \%}$ & $\mathbf{X}$ \\
\hline
\end{tabular}

Table 1 - Shows comparisons between the profile of the evaders and the general profile of the enrolled students.

Table 2 Shows comparisons between the profile of the evaders and the general profile of the enrolled students. Analyzing the typical characteristics of the dropout students it was observed that the minority of the students left their courses, consequently, most of the dropout students left their courses, that is, they 
asked for the definitive exclusion of their enrollments. In relation to the time taken by the students before these dropout, the majority of the students dropouted in the first semester of their courses. The representativity of the dropouts decreases as the period elapsed increases.

\begin{tabular}{|c|c|c|c|c|c|c|c|}
\hline \multicolumn{2}{|r|}{ abondonment } & $\begin{array}{l}\text { aftended } \\
\text { less } \\
\text { then } 6 \\
\text { monthes }\end{array}$ & $\begin{array}{c}\text { thended } \\
\text { behween } \\
6 \\
\text { months } \\
\text { ind hrif } \\
\text { year }\end{array}$ & $\begin{array}{c}\text { ffended } \\
\text { behween } \\
\text { a year } \\
\text { and a } \\
\text { yeur and } \\
\text { herf }\end{array}$ & $\begin{array}{l}\text { athended } \\
\text { behween a } \\
\text { yenr and hinf } \\
\text { and two } \\
\text { yenss }\end{array}$ & $\begin{array}{c}\text { aftended } \\
\text { between } \\
\text { bwo and } \\
\text { three } \\
\text { yeurs }\end{array}$ & $\begin{array}{l}\text { oflended } \\
\text { more thet } \\
\text { three } \\
\text { yenss }\end{array}$ \\
\hline $\begin{array}{l}\text { Dropout } \\
\text { Dropout (x) }\end{array}$ & $\begin{array}{c}25 \\
15,43 \%\end{array}$ & $\begin{array}{c}60 \\
37,04 \% \\
\end{array}$ & $\begin{array}{c}48 \\
29,63 \% \\
\end{array}$ & $\begin{array}{c}32 \\
19,75 \% \\
\end{array}$ & $\begin{array}{c}5 \\
3,09 \% \\
\end{array}$ & $\begin{array}{c}5 \\
3,09 \% \\
\end{array}$ & $\begin{array}{c}12 \\
\mathbf{7 , 4 1 \%} \\
\end{array}$ \\
\hline
\end{tabular}

Table 2 - Shows the profile of students who dropouted your studies.

\section{Discussion}

For Rattner (1999), sustainability passes through the mobilizing and motivating factor in society's efforts to transform social institutions, behavior patterns, and dominant values into Public Policy practices for quality, access and permanence education.

In agreement with the study by Gaioso (2005), the study of this research converges to a better application of the public resources, aiming the professional, human and cultural formation for the sustainable balance of our actions. According to Cislaghi (2008) permanence is the situation in which the student maintains the interest, the motivation and finds in the Institution of Higher Education (IHE) the essential conditions to continue attending regularly the superior course in which it has entered, work to be carried out with the educational sectors and with the management team of the Campus under study.

The researches conducted on the subject, given the lack of consensus, present several interpretations. Two similar but not identical aspects stand out: "average annual avoidance", which measures the percentage of students enrolled in a course or institution, which in the following year will not enroll; and "total dropout", which shows the number of students enrolled who did not complete the course after their regular offering period (SILVA FILHO et al, 2007).

"Effects of the Quotas Policy at the University of Brasilia: an analysis of income and dropout" (CARDOSO, 2008) has as object of study the quota system of the University of Brasilia (UnB), which was instituted in 2003. It is worth mentioning the analysis that the author presents on the avoidance of quota students in UnB, assuming that the abandonment is associated with family income and academic income. In this sense, avoidance would be higher in the universe of quota students than in non-quota students, which is opposed to the results found in technological higher education courses, Campus Macapá.

A study by Cunha et al. (2014), whose objective was to identify the variables that could determine the avoidance of students of the Accounting Sciences course in public IHE in their first year of graduation seeking to analyze the socio-economic characteristics of these students found that $50 \%$ of the students are 
of the genre $89 \%$ are single and the average age of respondents is 20.8 years. It was also found that, although most of the students (56\%) had attended most of the high school in the public school, only $30 \%$ joined the University by some quota system. These data differ from those found in the secondary data obtained from the academic record of the Macapá campus, which individualizes the profile of the dropout, except for the quota criterion.

\section{Conclusion}

The problem of dropout in technological higher education courses at IFAP, Campus Macapá can be considered a cause for concern, possibly tending to be further aggravated by the fact that the large number of students who did not finish their courses in the expected duration of their courses represent potential dropout.

The reasons and causes of evasion can not be analyzed outside a broader historical context, as it reflects the reality of the country, that is, evasion in IHEs is a complex phenomenon. It is important for the institution to provide a systematic follow-up process to students who present learning difficulties, high absences, social, economic or psychological vulnerability in order to anticipate and try to restrain these students in the institution, thus avoiding your exit. Such advances would enable the responsible sector to take a more direct and preventive action to reduce student exodus.

We highlight the presence of two tendencies in the profile of the subjects of the present research that are not debated in the bibliography that was taken by base in the present work. The first is the low time taken by students when they decide to dropout, and the second is the definitive character of evasion, since the great majority of teachers have asked for the exclusion of their enrollments. This tendency may be associated with students' lack of knowledge about the courses they have chosen and, after a brief period of experimentation, they conclude that they do not identify with the course. It is suggested that this hypothesis be confirmed by means of a qualitative investigation, or even by means of a field in the form of desistence of the students who request the dismissal of their enrollments where, wanting, the student can express the reasons for their decision.

The qualification of the dropouts seems to be one of the serious problems for the effective schooling. Consequently one of the greatest adversities for the technological higher education courses, Campus Macapá, demanding actions that guarantee the improvement of efficiency and effectiveness, change in the form of management and focus on the needs of the student.

As a contribution, propose improvements in the form of pedagogical and psychosocial care, options that can identify the factors related to the individual characteristics of the student, internal factors referring to the courses of technological higher education, Macapá Campus and factors external to the Institution, listed by the authors Bardagi et al (2003); Scali(2009); Mercuri e Polydoro(2003); e Veloso (2000).

It is proposed to include in the future work options that can identify the factors related to the individual characteristics of the student (educational skills, personality, previous schooling, difficulties, incompatibility between academic life and professional life requirements, demotivation with the course chosen) in order to identify potential students who have a tendency to evade or abandon courses, thus carrying out specific work, aiming at the permanence of this student by attending to their conditions, taking into account the aspects traced in the profile of the evaded, such as students above 26 years of age, 
males attending the first semester of the course.

\section{References}

BARDAGI, M. P; LASSANCE, M.C.P; PARADISO, A. C. Trajetória acadêmica e satisfação com a escolha profissional de universitários em meio decurso. Revista Brasileira de Orientação Profissional, v. 4, n.1, p. 153-166, 2003.

CARDOSO, C. B. Efeitos da política de cotas na Universidade de Brasília: uma análise do rendimento e da evasão. Dissertação de Mestrado em Educação. Brasília, 2008.

CISLAGHI, R. Um modelo de sistema de gestão do conhecimento em um framework para a promoção da permanência discente no ensino de graduação. Tese de Doutorado. Florianópolis, 2008.

CUNHA, J. V. A; NASCIMENTO E. M; DURSO, S. O. Razões e influências para a evasão universitária: um estudo com estudantes ingressantes nos cursos de Ciências Contábeis de instituições públicas federais da Região Sudeste. São Paulo, 2014.

GAIOSO, N.P. L..O fenômeno da evasão escolar na educação superior no Brasil. 75 f. Dissertação (Mestrado em Educação) - Programa de Pós-Graduação em Educação da Universidade Católica. Brasília, 2005.

GIL, A.C. Métodos e técnicas de pesquisa social. 6 ed. Editora Atlas, São Paulo: 2009

LOBO, M.B.C; Panorama da evasão do ensino superior brasileiro: aspectos gerais das causas e soluções. Publicado no ABMES, caderno nº 25. São Paulo, 2012.

MERCURI, E. N. G. S.; POLYDORO, S. A. J. O compromisso com o curso no processo de permanência/evasão no ensino superior: algumas contribuições. In: MERCURI, E.; POLYDORO, S. (Orgs.) Estudante universitário: características e experiências de formação. Taubaté: Cabral Editora e Livraria Universitária, 2003.

PEREIRA, M.L.T. A aventura da Universidade. Revista Interface, p.201-204. São Paulo, 1997.

RATTNER, H. Sustentabilidade - uma visão humanística. Revista Ponto de Vista. Ambiente e Sociedade - Ano II - n 5 - 2 semestre de 199. São Paulo, 1999.

SCALI, D. F.. Evasão nos Cursos Superiores de Tecnologia: A percepção dos estudantes sobre seus determinantes. 2009. 140 f. Dissertação de Mestrado em Educação. Campinas, 2009.

SILVA, E. L.. Metodologia da pesquisa e elaboração de dissertação. 4. ed. rev. atual. - Florianópolis: UFSC, 2005.

STALLIVIERI, Luciane. O Sistema de ensino superior do Brasil. Características, tendências e perspectivas, 2006. 
SILVA FILHO, R. L. L; MOTEJUNAS, P. R.; HIPÓLITO, O; LOBO, M. B.C. A Evasão no Ensino Superior Brasileiro. Instituto Lobo para o Desenvolvimento da Educação, da Ciência e da Tecnologia. 2007.

VELOSO, T. C. M. A. Evasão nos cursos de graduação da Universidade Federal de Mato Grosso, Campus universitário de Cuiabá: um processo de exclusão. Dissertação de Mestrado. Campo Grande, 2000.

VOLPI, O. J. A relação ciência, tecnologia e sociedade: o ensino superior tecnológico e sua concepção, Santa Catarina, 2009.

[1] Civil Engineer. Master in Civil Engineering. Professor and Researcher at the Federal Institute of Amapá - IFAP

[2] Biomedical. PhD in Tropical Diseases. Professor and Researcher at the Federal University of Amapá, AP. Collaborating researcher at the Tropical Medicine Nucleus of UFPA (NMT-UFPA).

${ }^{[3]}$ Biologist. Doctor of Medicine / Tropical Diseases. Professor and Researcher at the Federal University of Pará - UFPA

${ }^{[4]} \mathrm{PhD}$ in Clinical Psychoanalysis, Researcher by the Center for Research and Advanced Studies

[5] Biologist. Doctor in Theory and Research of Behavior. Professor and Researcher of the Federal Institute of Amapá - IFAP. Collaborating researcher at the Núcleo de Núcleo de Estudos em Pesca e Aquicultura de UNIFAP (NEPA-UNIFAP).

\section{PUBLIQUE SEU ARTIGO CIENTÍFICO EM:}

https://www.nucleodoconhecimento.com.br/enviar-artigo-cientifico-para-submissao 